\title{
Factor Analysis of the Effects of the Introduction of English Supplementary Education to Future Classrooms
}

\author{
Chin-Long Hsu ${ }^{1}$, Ming-Chih Chen" ${ }^{1}$, Ben-Chang Shia ${ }^{2}$, Sheng-Ming Wang ${ }^{3}$ \\ ${ }^{1}$ Graduate Institute of Business Administration, Fu-Jen Catholic University, Taiwan \\ ${ }^{2}$ Graduate Institute of Data Science, Taipei Medical University, Taiwan \\ ${ }^{3}$ Department of Interaction Design, National Taipei University of Technology, Taiwan \\ Email: longhsu@gmail.com,081438@mail.fju.edu.tw, stat1001@tmu.edu.tw,ryan5885@mail.ntut.edu.tw
}

How to cite this paper: Hsu, C.-L., Chen, M.-C., Shia, B.-C. and Wang, S.-M. (2017) Factor Analysis of the Effects of the Introduction of English Supplementary Education to Future Classrooms. American Journal of Industrial and Business Management, 7, 386-403.

https://doi.org/10.4236/ajibm.2017.74028

Received: February 15, 2017

Accepted: April 21, 2017

Published: April 24, 2017

Copyright ( 2017 by authors and Scientific Research Publishing Inc. This work is licensed under the Creative Commons Attribution International License (CC BY 4.0).

http://creativecommons.org/licenses/by/4.0/

\begin{abstract}
This paper explores trends in the development of technological applications in education, attempts to identify key decision-making factors related to the transition from traditional classrooms to future classrooms, and seeks to determine and analyze the relationships between structural factors and their importance. This study investigates the future evolution of education and predicts possible pathways and strategic proposals related to educational evolution by observing previous modes of operation within traditional education and traditional education models, investigating operational and structural modes within the current educational environment, and studying solutions to current problems and the accomplishment of educational reforms. Using a service design workshop, we explore key factors affecting English education in the classrooms of the future, conducting analysis by addressing the interaction between operations management, flipped education, and modes of learning. This study investigates key factors related to the introduction of supplementary English education into future classrooms, in addition to providing valuable considerations and viewpoints related to the development of future classrooms. This study focuses on investments in the educational environment of future classrooms and brings educational resources into play to increase educational efficacy. The ability of supplementary education to quickly evolve away from traditional teaching styles is fostered by allowing for the continued operational development of Taiwan's supplementary education institutions. We hope that future technology and artificial intelligence will optimize learning environments and enable the establishment of a new paradigm in education.
\end{abstract}

\section{Keywords}

Future Classroom, Supplementary Education, Flipped Education, Service 
Design

\section{Introduction}

Educational projects are long-term, sustained, and forward-thinking processes. Education is offered for the development of all learners, in addition to representing the heritage of societies and cultures. Applications of digital learning and mobile technology in future educational systems are popular topics in international discussions, with many countries actively promoting a variety of digital learning and mobile education projects, in addition to establishing future smartteaching environments. A discussion of future learning is helpful to nurturing a new generation of talent and promoting overall competitiveness. The application of technology in teaching is a new trend in education development. This study explores the application of technology and trends in educational development, attempts to identify the key decision-making factors related to the transition from traditional classrooms to future classrooms, and analyzes the relationships among and the importance of the main structural factors.

As shown in Table 1, there were 18,649 cram schools in Taiwan as of April 4, 2016. There were 18,499 cram schools in 2015 , compared to 11,474 in 2007, representing an increase of 7025 schools, or a growth of $61.23 \%$. According to data covering 2013 to 2015, 4552 new cram schools were established during this period. During the most recent three years, there was a net addition of 2155 schools, although 2397 closures occurred in this period. The current scale of cram schools is thus approaching saturation and entering a stage of high competition and frequent closures. Of the total, 11,011 schools (59\%) were for language studies and related disciplines, while 4676 schools (25\%) were for foreign language studies; combined, these account for 15,687 schools (84\%). These statistics

Table 1. Changes in the number of cram schools in Taiwan.

\begin{tabular}{ccccc}
\hline Year & $\begin{array}{c}\text { Number of } \\
\text { Cram Schools }\end{array}$ & Language-related & Skill-related & $\begin{array}{c}\text { Language Schools } \\
\% \text { of Total }\end{array}$ \\
\hline 2007 & 11,474 & 9528 & 1946 & $83.04 \%$ \\
2008 & 12,662 & 10,555 & 2107 & $83.36 \%$ \\
2009 & 13,708 & 11,446 & 2262 & $83.50 \%$ \\
2010 & 14,796 & 12,361 & 2435 & $83.54 \%$ \\
2011 & 15,585 & 13,034 & 2551 & $83.63 \%$ \\
2012 & 16,344 & 13,707 & 2637 & $83.87 \%$ \\
2013 & 17,040 & 14,309 & 2731 & $83.97 \%$ \\
2014 & 17,811 & 14,975 & 2836 & $84.08 \%$ \\
2015 & 18,499 & 15,557 & 2942 & $84.10 \%$ \\
2016 & 18,649 & 15,687 & 2962 & $84.12 \%$ \\
\hline
\end{tabular}


indicate that language studies remain the key focus of cram school operations. English studies constitute the core language studies program, followed by Japanese studies.

The definition of "supplementary learning" implies the study of specific fields. Supplementary learning is generally used to strengthen students' competence in particular subjects relatively quickly, although cram schools are non-formal. Supplementary education is also referred to as "shadow education." Scholars believe that extracurricular supplementary education occurs only alongside mainstream education and that its scale and form change along with changes in mainstream education [1]. In virtually all societies, supplementary education receives less attention than mainstream education, and its nature is far less clear and identifiable. The mainstream education subjects that are best able to improve enrolment rates and employment opportunities, such as languages, mathematics, and sciences, are the most popular in supplementary education. Cram schools are generally private organizations. They are very popular in many East Asian countries and regions, such as Japan, Taiwan, Singapore, South Korea, Mainland China, and Hong Kong. Such countries and regions have been influenced by Confucianism and have histories of private education and imperial examination systems. Cram schools serve as an educational system unto themselves in these regions, with many students attending supplementary education after standard classes.

Supplementary education faces the following challenges:

1) Modern modes of learning: In an era of information overload, the questions of how to increase knowledge quality, study well, study correctly, and study effectively have become significant. In line with modern "fast-food" culture, educational culture, and educational modes, the questions of how to improve real learning and provide richer educational content will pose significant tests for the future of education.

2) The market mechanism of perfect competition: According to Taiwanese national education statistics, new players continue to enter the supplementary education market. However, applicant revocations continue to rise, showing that the market is exhibiting saturation and is entering a state of perfect competition.

3) Responding to the shock of a shrinking population: Due to Taiwan's declining birthrate and the resulting shrinkage of the student population, operational restructuring is underway in Taiwan's school system, with some schools beginning to offer various skill-related and after-school services, thus shocking the supplementary education market.

4) Reduced teaching time: The Taiwanese government implemented a twoday weekend to improve Taiwanese living standards; the increased leisure time for families has led to a time-squeezing effect and a compression of supplementary education study time.

Educational projects are long-term, and the quality of educational efficacy is an important factor affecting national economic development. Nurturing highquality industrial talent requires that the education of technical talent be im- 
proved; thus, excellent basic education is very important [2]. Recent improvements in computing and mobile technologies have provided a good developmental basis for teaching and learning environments; although digital technologies provide for more developmental and convenient learning, learners still face restrictions related to their learning environments and tools and do not receive complete educational support across different learning environments. Therefore, demand will grow for more intelligent, actionable, interactive, and borderless teaching and learning environments. This is the objective that "ubiquitous learning" hopes to achieve. Traditional digital whiteboards are expensive and provide limited flexibility and efficacy, while the use of tablet computers as digital book bags often serve only as replacements for textbooks or book bags and cannot fully meet the needs of interactive learning environments.

Japanese education expert Sato Manabu has proposed the concept of the "learning community," which has garnered much attention among Taiwanese education scholars. This concept emphasizes initiative, participation, sharing, cooperation, and expression and is helpful in encouraging proactive learning in students, in addition to cooperation and sharing of experiences in traditional classroom settings. Teachers who incorporate information technology into their classroom management are able to promote interactive teaching and can quickly provide feedback and coordinate group cooperation functions, in addition to increasing the efficacy of class management [3].

This paper will introduce the concept and significance of Future Classrooms, and focuses on investments in the educational environment of future classrooms and brings educational resources into play to increase educational efficacy. This study investigates key factors related to the introduction of supplementary English education into future classrooms, in addition to providing valuable considerations and viewpoints related to the development of future classrooms.

\section{Literature Review}

\subsection{Future Classrooms and Blended Learning}

The "future classroom" notion refers to the use of a variety of hardware, software and information technology equipment to revitalize the efficacy of teaching and enable the automatic formation of curriculum content in technological teaching environments. When future classrooms combine internet communications with system platforms, they will be better able to achieve the digital learning goals of "teach once and apply often" and "teach onsite and share remotely," the new teaching framework sought by teachers, students, and management units [4]. The primary purpose and core concept of the future classroom is to enhance students' learning motivation and efficiency through an interactive environment and varied teaching content, as well as to enhance teaching and classroom management so that teachers can adjust teaching progress and content at any time, thus allowing for the optimization of teaching and learning results. A program combining equipment with system hardware and software will help future schools find the optimal methods of facing issues related to "smart" 
learning environments. Education solutions can provide end-to-end hardware/software products and services. In addition to enhancing interactive learning, collaboration, and learning efficacy, these solutions can also assist teachers with classroom management. The primary and secondary schools of the future are expected to gradually deploy future classroom platforms, which will help Taiwan's education environment to evolve quickly from traditional classroom teaching styles to future "smart" classroom environments.

Taiwan's first future classroom is located in Taipei City's Nanhu Elementary School; its future classroom capabilities are the following: 1) the use of touch projection technology and the establishment of flexible variable learning spaces provide students with an experiential learning environment; 2 ) the use of digital photography technology, integrated digital photography, and remote video capabilities provides students with interdisciplinary learning spaces; and 3) the use of internet broadcasting technology enables highly interactive teaching and the implementation of cooperative exploration, in addition to a networked community learning environment. Entering a future classroom is a novel experience, and the environment attracts students' interest. The interactive teaching materials, self-operation, animated effects, specific presentation of materials, and interactions among classmates instill deeper memories and further the goal of improving students' learning efficacy and attitudes. Furthermore, the use of information technology equipment is an extra bonus when studying in future classrooms and is believed to allow students and teachers to improve their ability to incorporate information technology into teaching and learning. Xiao Fusheng, principal of Nanhu Elementary School, stated that the keys to open mobile learning are the following. 1) When offered differentiated and supplementary education through mobile learning, students are able to learn at different rates according to personal factors. 2) Following the "flipped classroom" concept, mobile learning education differs from traditional education in that the teaching method varies from student to student. 3) Establishing specialized groups for mobile learning, using communication and sharing observations regarding the implementation and development of new learning modes helps expand the digital book bag implementation process. 4) Finally, participation in experimental research and engaging in discussions on and the implementation of mobile learning projects allow the verification of learning outcomes through scientific methods.

Using $21^{\text {st }}$ century technology and blended learning environments to improve learning efficiency have been shown to provide high-quality education [5]. Blended learning, or hybrid learning, uses the convenience of the internet to assist learning, allowing for the study environment of real classrooms to run parallel with dual-track virtual online learning. Combining the strengths of internet technologies with those of face-to-face class attendance in a dual-track learning method strengthens learners' overall learning engagement and learning outcomes. This is achieved through interaction with classmates and teachers, extending learning opportunities, and improving learning outcomes. Blended 
learning has many definitions in the domestic and international literature; these can be summarized as follows: 1) user learning content from blends of different systems and operational processes; 2) blending different educational methods; and 3) blending different forms of educational technology in future classrooms, such as remote video instruction and mobile study, or interactive instruction [6]. Studies have shown that the learning outcomes and interest in learning of students who use blended learning increase significantly [7].

\subsection{Service Design}

Service design is used to integrate individuals, organizations, infrastructure, communications, and service-related elements. Through interactions between service users and service providers, service design activities are intended to increase service quality and to innovate services [8] [9] [10]. The concept of service design was first applied in 1991 by Professor Michaael Erlhoff of the Köln International School of Design. An interdisciplinary alliance was then formed with Carnegie Mellon University, Linköpings Universitet, Politecnico di Milano, and Domus Academy. This aided in the establishment of a service design network and expanded service design's application to the fields of product design and digital technology [11]. Service design's key difference from traditional design is that it is a product-focused way of thinking. As service design emphasizes product design, it requires the use of visualization tools to derive user environment experience analysis results. The concept also proposes solutions for product service systems and blueprints for implementation [10] [12] [13]. Service design is a user-oriented concept, and its application to the topic of supplementary English education within future classrooms is based on the creation of varied, interesting, easily utilized, and high-efficiency future learning spaces [14]. Through service design, users are introduced to innovative, situational experience-oriented, interdisciplinary design methods [13]. This mode of design thinking has been used by educational experts with various perspectives to analyze, observe, and confirm the promotion of many different applications within future education.

In this study, we focus on design thinking, using d. School's interdisciplinary integrated innovative design application model and methods as a blueprint [15]. We also engage with educators at a service design workshop, applying design thinking to explore and develop topics related to key factors in future classrooms. This is accomplished by collecting and analyzing scientific information, as well as by validating and evaluating the proposed innovation model in order to promote educational value and develop innovative modes of operation.

The application and operation model of design thinking used in this study is shown in Figure 1. This study explores the design thinking and assessment of the introduction of supplementary English education into future classroom learning modes. The key implementation steps are as follows: 1) explore education development trends and forward-looking application analysis, and propose future classroom development definitions; 2) organize workshops to conduct interdisciplinary brainstorming and the integration of disciplines to propose 


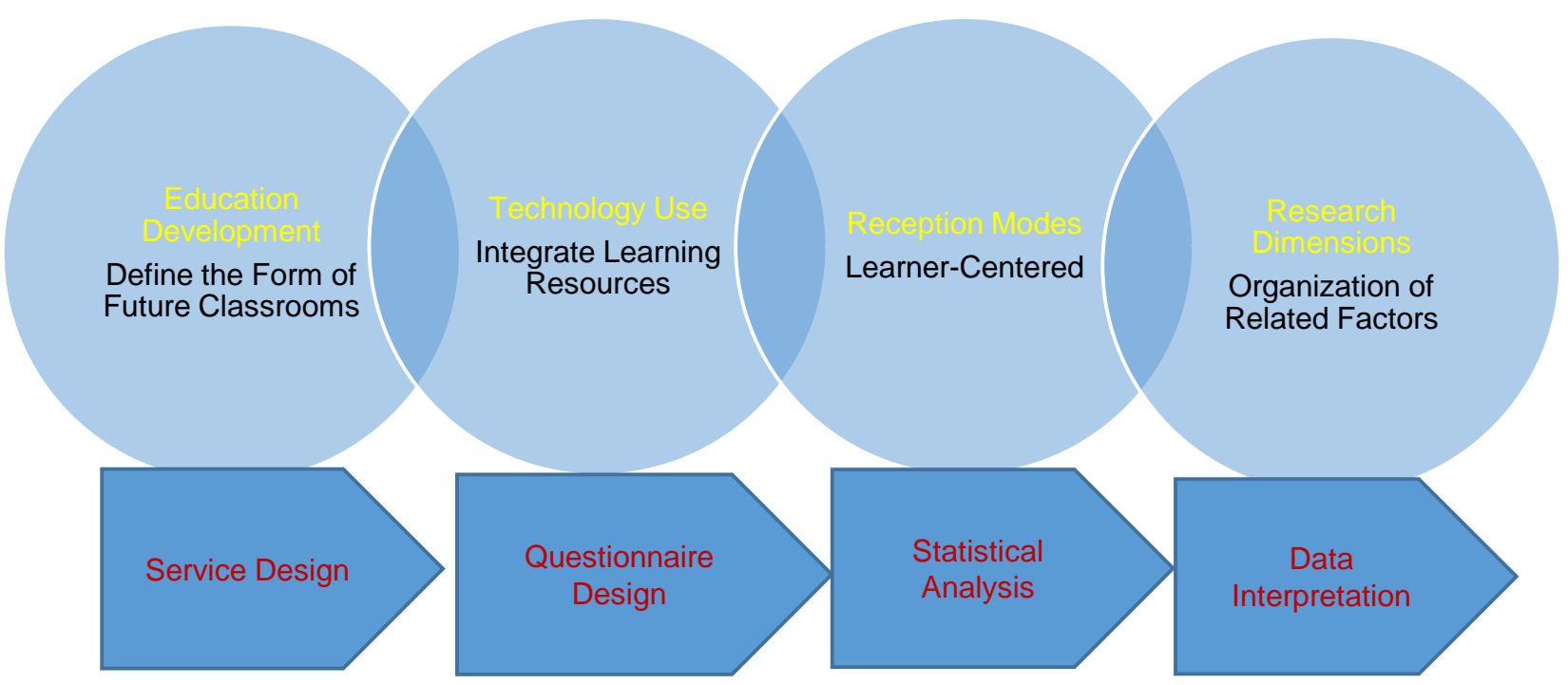

Figure 1. Design thinking application and operational modes.

interactive and integrated plans for the application of learning technology; 3) understand and explore learner-centered thinking and design, and develop definitions of user environment design and reception mode; 4) summarize and organize the definitions of influencing dimensions and present their key factors.

Scholars have proposed the use of design thinking to establish a conceptual axis for interdisciplinary integration, combined with a theoretical basis and methods of service design. The promotion of user experience-oriented innovative design and interdisciplinary innovative models remain the core focus of future digital technology and interactive design integration [10] [12]. The overall service design application process is shown in Figure 2. The figure shows how service design will drive service transformation and achieve the ultimate goal of service operation through user cycle design, user needs analysis, technology application development assessment, prototype system and interface construction, and user experience assessment.

\section{Methodology}

\subsection{Research Model and Hypotheses}

This study explores core topics affecting the promotion of supplementary language studies in future classrooms. Consistent with the research framework flowchart shown in Figure 3, we select content from the theme-based teaching materials of language learning, introduce the application of technology based on the content, and develop learning mechanisms for future classrooms, including exploration, experiment, experience, and empowerment. In addition, through the four goals of exploration, experiment, experience, and empowerment, we promote the interactive design of learning, the operation and use of technology systems, and the design of the learning environment, in addition to exploring the impact of learning success. Through the exploration of service design, influencing factors related to learning environments are analyzed, classified, and 


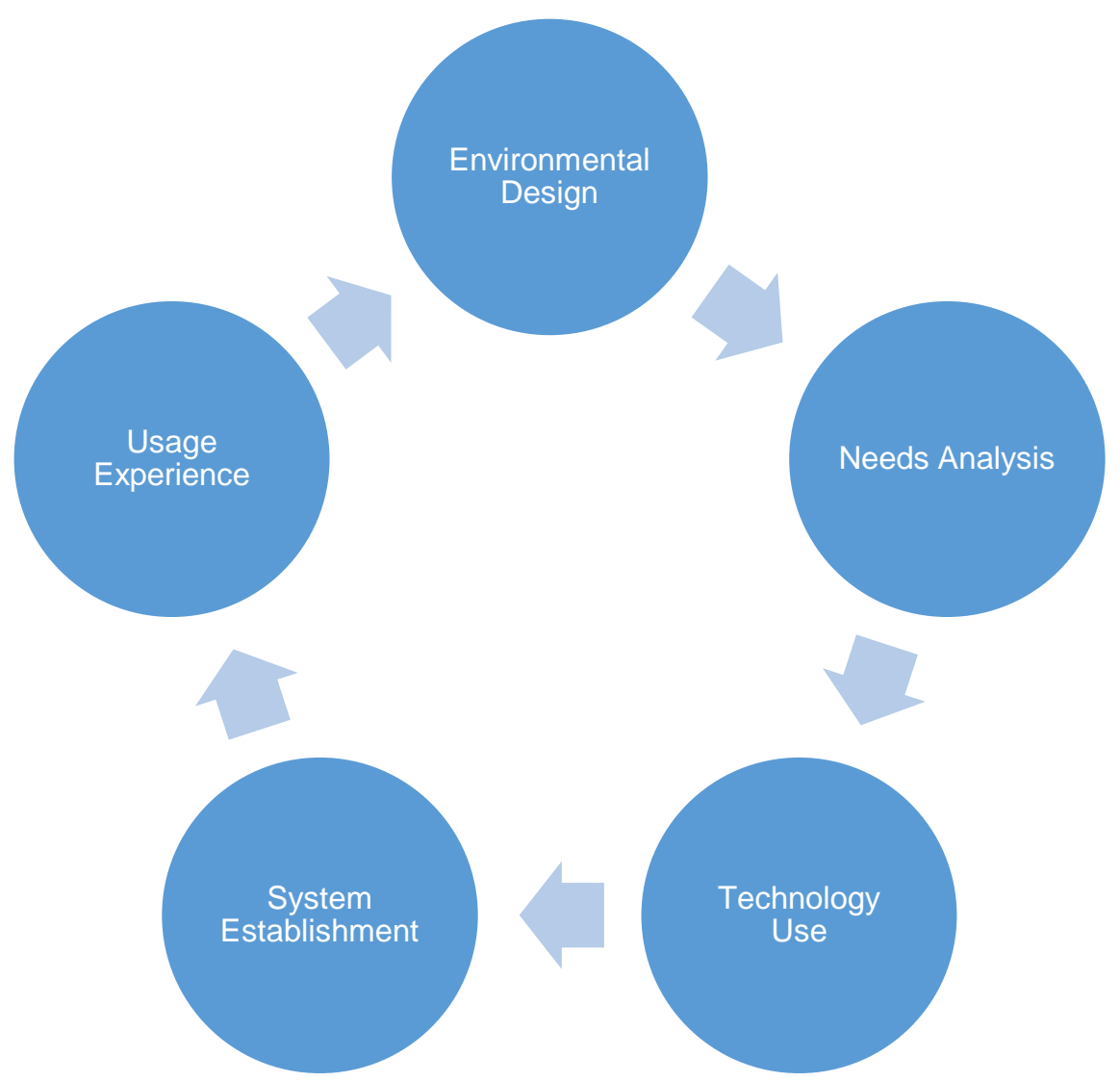

Figure 2. Service design operation.
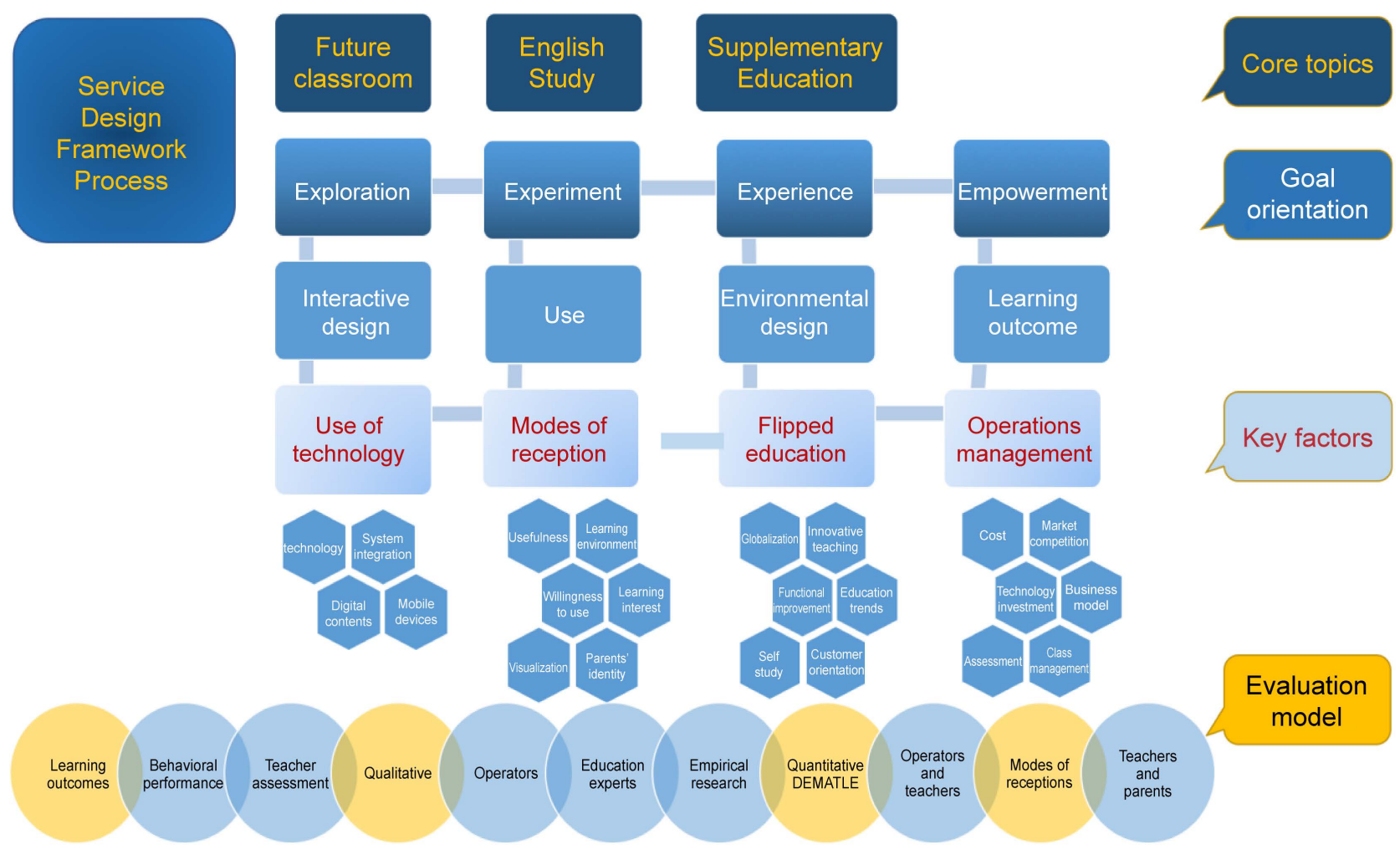

Figure 3. Service design structure flowchart. 
organized. We also establish four conceptual dimensions for our study: use of technology, modes of reception, flipped education, and operations management. Given current trends in technology use in future classrooms, three main conceptual dimensions-use of technology, flipped education, and modes of reception-are highlighted in this study. We intend to uncover the key influencing factors related to the promotion of future classrooms.

This study proposes the following hypotheses:

Hypothesis 1: The introduction of supplementary English education to future classrooms is positively correlated with the use of technology.

Hypothesis 2: The introduction of supplementary English education to future classrooms is positively correlated with operations management.

Hypothesis 3: The introduction of supplementary English education to future classrooms is positively correlated with flipped education.

Hypothesis 4: The introduction of supplementary English education to future classrooms is positively correlated with modes of reception.

Hypothesis 5: The key factors driving the introduction of future classrooms all exhibit positive effects on one another.

Hypothesis 6: The study design models of the introduction of future classrooms are positively correlated with operations investment benefits.

\subsection{Research Method}

The purpose of the decision-making trial and analysis method is to collect expert opinions from the Decision Making Trial and Evaluation Laboratory (DEMATEL). Principles related to matrices are used to grasp causal relationships within complex systems, to make optimized decisions, and to improve analysis and research methods for complex systems [16]. Because of the complexity of the impact of educational topics, we borrow from the DEMATEL approach to explore key factors in educational decision making related to the introduction of future classrooms, in addition to assessing the causal relationships between and relative importance of these factors. Furthermore, because of the complex relationships among the influencing factors in future classroom establishment and introduction, this study uses DEMATEL to identify these relationships using a cause-and-effect diagram. This diagram enables us to clearly determine the relative importance of the selection dimensions, identify their causal relationships, and help improve sustained school management.

This study collected data using questionnaires. The questionnaire content was designed with reference to our literature review and service design research framework. It was used to analyze and assess the influencing factors of the introduction of supplementary English education to future classrooms. Drawing on the experience of experts, the questionnaire reveals the respondents' attitudes to the key factors related to the feasibility of supplementary education in future classrooms; it also performs a quantitative analysis of dimensional factors and uses the DEMATEL method to analyze the causal relationships among the decision-making assessment factors. The questionnaire explores the key educational 
decision-making factors related to the introduction of future classrooms and thus serves as an effective and valuable reference. The definitions of the dimensional variable factors in this study are shown in Table 2.

\subsection{Sampling}

This study invited education experts to respond to questionnaires addressing topics related to future classrooms. Educational experts must meet the following qualification that is to have the practical experience in the field of educational industry. The sampling was used by taking a random sampling method to invite the experts to participate in this study. These experts included managers from the education and cram school industries, English education experts (both Taiwanese and language teachers from other countries), and individuals working in administrative education management. The results of these questionnaires were statistically analyzed by gender, nationality, age, education level, years of work experience, and profession. The results were then arranged and explained in a table.

\section{Empirical Result and Analysis}

The questionnaire was planned and executed as an expert questionnaire, in which experts were invited as subjects with practical experience in education.

Table 2. Dimensional variable factor definitions.

\begin{tabular}{|c|c|}
\hline Research Dimension Variable & Definition \\
\hline $\begin{array}{l}\text { Operations management: modes of use } \\
\text { and maintenance }\end{array}$ & $\begin{array}{l}\text { Plans for supplementary education studies and } \\
\text { service models for course content transmission }\end{array}$ \\
\hline $\begin{array}{l}\text { Operations management: technology } \\
\text { investment }\end{array}$ & Total cost of investment in technological equipment \\
\hline $\begin{array}{l}\text { Operations management: market } \\
\text { competition }\end{array}$ & $\begin{array}{l}\text { Mechanisms in response to industrial development } \\
\text { related to study }\end{array}$ \\
\hline $\begin{array}{l}\text { Operations management: classroom } \\
\text { operation }\end{array}$ & Ability to effectively control classroom management \\
\hline Flipped education: education trends & $\begin{array}{l}\text { Mobile education behavior in response to } \\
\text { transformation of mainstream education }\end{array}$ \\
\hline Flipped education: education innovation & $\begin{array}{l}\text { Innovation and breakthroughs compared to } \\
\text { traditional education }\end{array}$ \\
\hline Flipped education-self study & $\begin{array}{l}\text { Individual learning content and individualized } \\
\text { curriculum }\end{array}$ \\
\hline $\begin{array}{l}\text { Flipped education: functional } \\
\text { improvements }\end{array}$ & $\begin{array}{l}\text { Effective use of instruction and positive learning } \\
\text { outcomes }\end{array}$ \\
\hline Reception modes: learning environment & Acceptance of technological learning environments \\
\hline Reception modes: learning motivations & $\begin{array}{l}\text { Self-motivation and interactivity related to the } \\
\text { use of technologically enabled learning methods }\end{array}$ \\
\hline Reception modes: willingness to use & Willingness to use new modes of learning \\
\hline Reception modes: learning outcomes & $\begin{array}{l}\text { Learning outcomes as a result of the use of } \\
\text { future classrooms }\end{array}$ \\
\hline
\end{tabular}


These experts included managers, education experts, English language teachers, and administrative managers. This information is summarized in Table 3.

\subsection{Cause-and-Effect Diagram Analysis}

The 12-dimensional cause-and-effect diagram in Figure 4 shows the complex causal relationships among dimensional factors. The five dimensions of "A02: Technology Investment," “A06: Innovative Teaching," “A09: Learning Environment," “A10: Learning Motivation," and “A12: Learning Outcomes” are located

Table 3. Expert statistics.

\begin{tabular}{|c|c|c|}
\hline Item & \# of people & $\%$ \\
\hline \multicolumn{3}{|l|}{ Gender } \\
\hline Female & 20 & $49 \%$ \\
\hline Male & 21 & $51 \%$ \\
\hline \multicolumn{3}{|l|}{ Nationality } \\
\hline Foreign & 10 & $24 \%$ \\
\hline Taiwanese & 31 & $76 \%$ \\
\hline \multicolumn{3}{|l|}{ Age } \\
\hline 30 and younger & 4 & $10 \%$ \\
\hline $31-40$ & 11 & $27 \%$ \\
\hline $41-50$ & 16 & $39 \%$ \\
\hline $51-60$ & 9 & $22 \%$ \\
\hline 61 and older & 1 & $2 \%$ \\
\hline \multicolumn{3}{|l|}{ Education level } \\
\hline University & 15 & $37 \%$ \\
\hline High School/Vocational & 1 & $2 \%$ \\
\hline Specialist & 4 & $10 \%$ \\
\hline Ph.D. & 3 & $7 \%$ \\
\hline Master's & 18 & $44 \%$ \\
\hline \multicolumn{3}{|l|}{ Work experience } \\
\hline $1-5$ years & 4 & $10 \%$ \\
\hline $6-10$ years & 3 & $7 \%$ \\
\hline $11-15$ years & 12 & $29 \%$ \\
\hline $16-20$ years & 9 & $22 \%$ \\
\hline 20 years and greater & 13 & $32 \%$ \\
\hline \multicolumn{3}{|l|}{ Profession } \\
\hline Administrative management & 6 & $15 \%$ \\
\hline Education expert & 1 & $2 \%$ \\
\hline Professor & 20 & $49 \%$ \\
\hline Operator & 14 & $34 \%$ \\
\hline
\end{tabular}




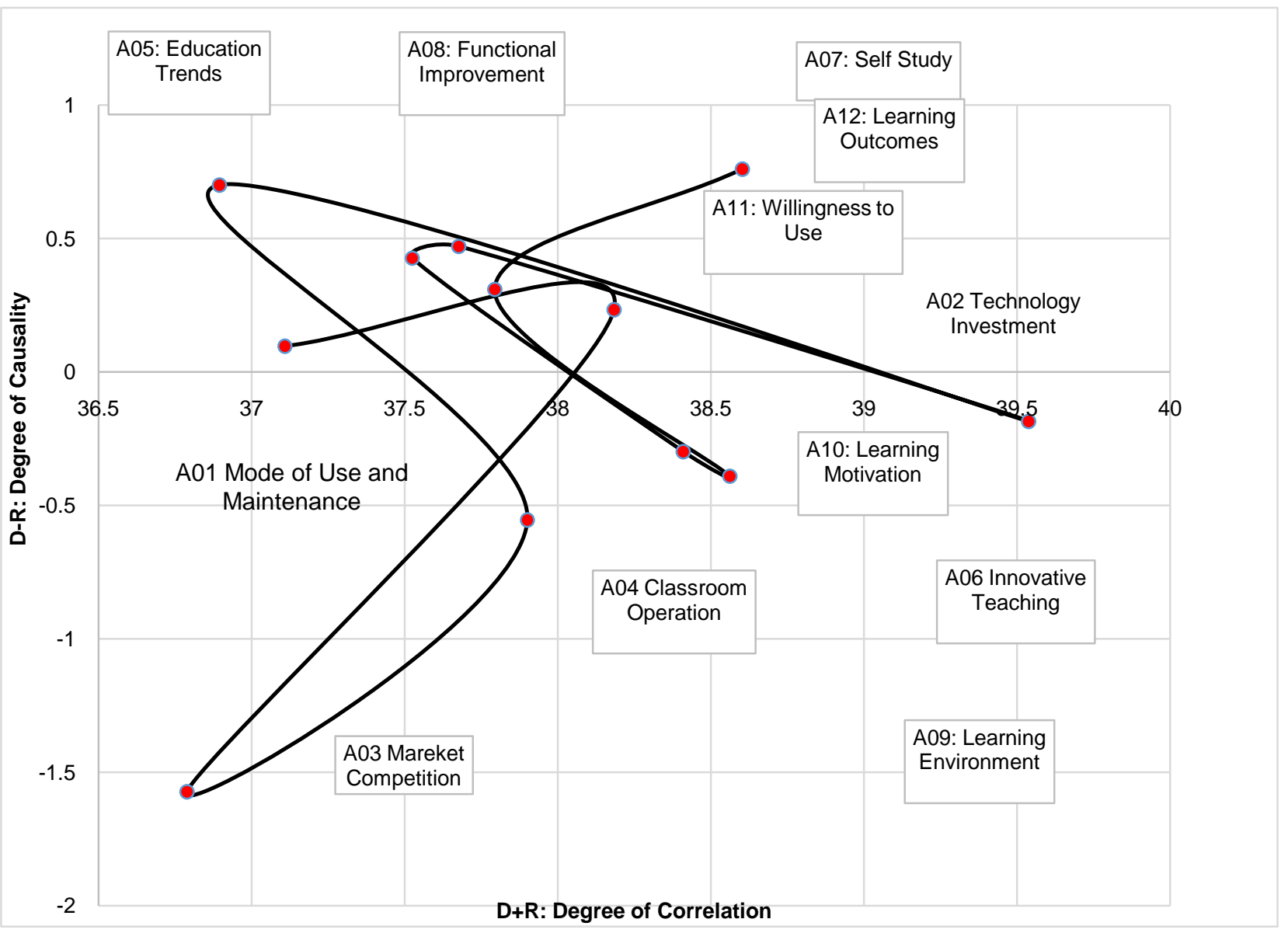

Figure 4. Cause-and-effect diagram for 12 dimensions. Threshold $=1.58$.

to the right on the correlation axis $(\mathrm{D}+\mathrm{R})$, also called "centrality." The correlations $(D+R)$ of these five dimensions are all greater than 37.92. Thus, these five dimensional factors have strong correlations relative to other dimensions. In addition, seven dimensional factors have degrees of causality $(D-R)$ greater than 0: "A01: Maintenance and Operation Mode," "A02: Technology Investment," "A05: Independent Study," "A08: Functional Improvement," "A11: Willingness to Use," and "A12: Learning Outcomes." This shows that they are causal dimensions (i.e., they are causes in the cause-and-effect relationship). Dimensions with degrees of causality $(\mathrm{D}-\mathrm{R})$ less than 0 are affected dimensions (i.e., effects in the cause-and-effect relationship). These are "A03: Market Competition," "A04: Classroom Management," "A06: Innovative Teaching," "A09: Learning Environment," and "A10: Learning Motivation." As Figure 4 shows, dimensions with higher correlation $(\mathrm{D}+\mathrm{R})$ are of greater importance for decision making in the transition from traditional to future classrooms. Decision making involves different selection methods for different dimensions; thus, the most effective implementation method must be selected. Among the 12 dimensions, decisions will be made according to the following, as they exhibit high correlation: "A02: Technology Investment," “A06: Innovative Teaching," "A09: Learning Environment," “A10: Learning Motivation,” and “A12: Learning Outcomes.” A nega- 
tive degree of causality $(D-R)$ indicates affected dimensions. The benefits derived from decisions made on the basis of these dimensions will be smaller due to the lack of room for improvement. Given their degrees of causality (D - R), the following seven dimensions are causal: "A01: Maintenance and Operation Mode," “A02: Technology Investment," “A05: Educational Trend," “A07: Independent Study," “A08: Functional Improvement," “A11: Willingness to Use," and "A12: Learning Outcomes." Based on correlation $(D+R)$ and degree of causality $(\mathrm{D}-\mathrm{R})$, the optimal decision-making factors are "A2: Technology Investment" and "A12: Learning Outcomes."

\subsection{Correlation Analysis}

In our analytical study of the influencing factors related to the introduction of supplementary English education to future classrooms, items A06, A12, and A10 (shown in the thick-lined boxes in Figure 5) are ranked as the top three items (see Table 4) because of their levels of correlation $(D+R)$. Thus, "A06: Innovative Teaching," “A12: Learning Outcomes," and “A10: Learning Motivation" are the most important decision-making assessment factors. Additionally, we see from the relationship diagram (Table 5) that "A03: Market Competition," "A05: Education Trends," and "A01: Mode of Operation and Maintenance" rank as the bottom three items due to their levels of correlation $(D+R)$. Thus, these three

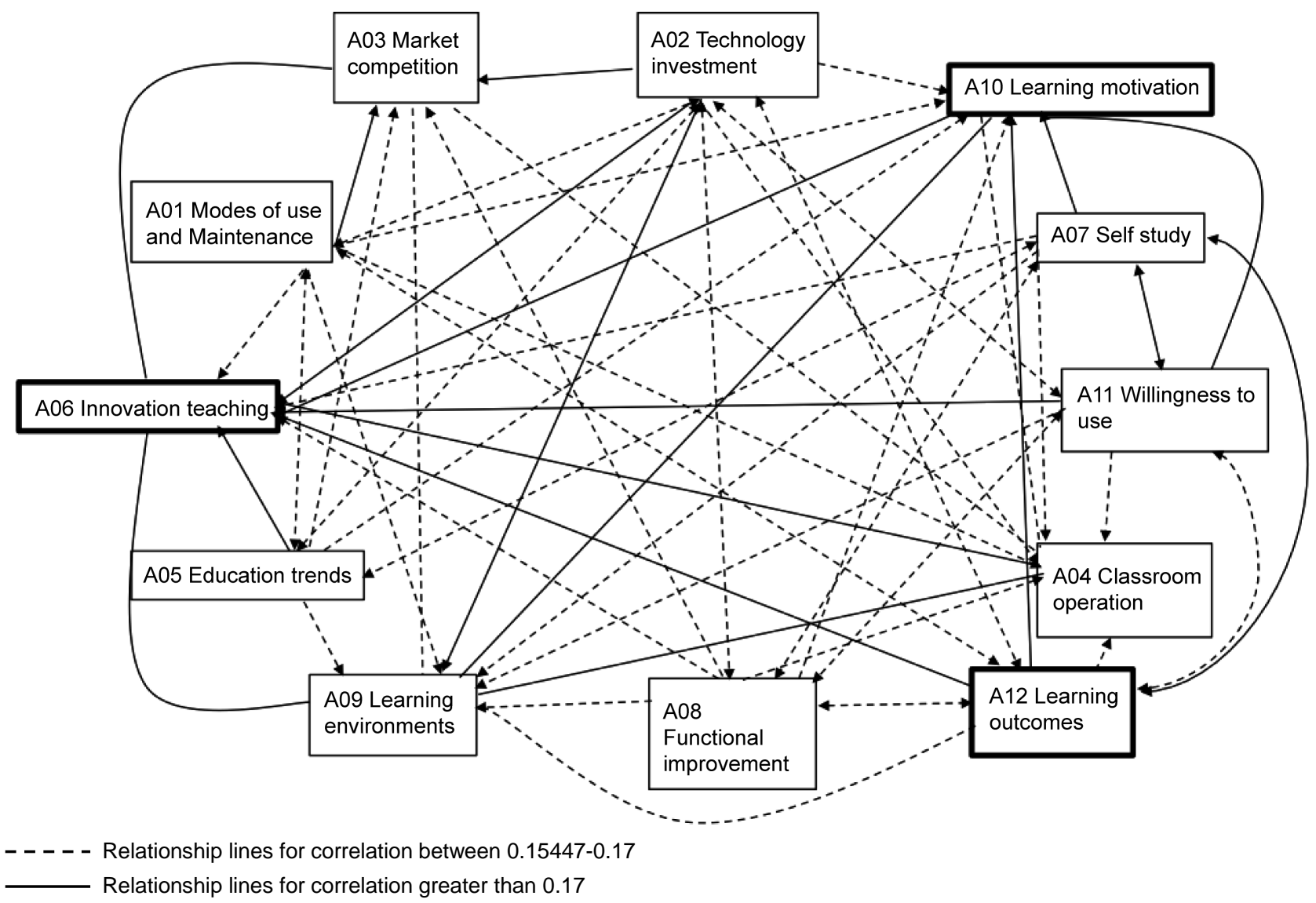

Figure 5. Relationship diagram for decision-making assessment factors. 
Table 4. Total effect relationship matrix.

\begin{tabular}{|c|c|c|c|c|c|c|c|c|c|c|c|c|}
\hline & $\begin{array}{c}\text { A01 } \\
\text { Mode of Use } \\
\text { and Maintenance }\end{array}$ & $\begin{array}{c}\text { A02 } \\
\text { Technology } \\
\text { Investment }\end{array}$ & $\begin{array}{c}\text { A03 } \\
\text { Market } \\
\text { Competition }\end{array}$ & $\begin{array}{c}\text { A04 } \\
\text { Classroom } \\
\text { Operation }\end{array}$ & $\begin{array}{c}\text { A05 } \\
\text { Education } \\
\text { Trends }\end{array}$ & $\begin{array}{c}\text { A06 } \\
\text { Innovative } \\
\text { Teaching }\end{array}$ & $\begin{array}{c}\text { A07 } \\
\text { Self } \\
\text { Study }\end{array}$ & $\begin{array}{c}\text { A08 } \\
\text { Functional } \\
\text { Improvement }\end{array}$ & $\begin{array}{c}\text { A09 } \\
\text { Learning } \\
\text { Environment }\end{array}$ & $\begin{array}{c}\text { A10 } \\
\text { Learning } \\
\text { Motivation }\end{array}$ & $\begin{array}{c}\text { A11 } \\
\text { Willingness } \\
\text { To Use }\end{array}$ & $\begin{array}{c}\text { A12 } \\
\text { Learning } \\
\text { Outcomes }\end{array}$ \\
\hline $\begin{array}{l}\text { A01 Mode } \\
\text { of Use and } \\
\text { Maintenance }\end{array}$ & 0.076 & 0.17 & 0.174 & 0.162 & 0.156 & 0.167 & 0.148 & 0.148 & 0.162 & 0.159 & 0.148 & 0.152 \\
\hline $\begin{array}{l}\text { A02 } \\
\text { Technology } \\
\text { Investment }\end{array}$ & 0.169 & 0.08 & 0.183 & 0.164 & 0.157 & 0.175 & 0.152 & 0.155 & 0.171 & 0.162 & 0.162 & 0.154 \\
\hline $\begin{array}{l}\text { A03 Market } \\
\text { Competition }\end{array}$ & 0.168 & 0.17 & 0.075 & 0.153 & 0.145 & 0.155 & 0.135 & 0.142 & 0.156 & 0.144 & 0.141 & 0.137 \\
\hline $\begin{array}{l}\text { A04 } \\
\text { Classroom } \\
\text { Operation }\end{array}$ & 0.155 & 0.152 & 0.156 & 0.079 & 0.151 & 0.164 & 0.156 & 0.157 & 0.166 & 0.166 & 0.157 & 0.167 \\
\hline $\begin{array}{l}\text { A05 } \\
\text { Education } \\
\text { Trends }\end{array}$ & 0.165 & 0.164 & 0.166 & 0.161 & 0.075 & 0.175 & 0.156 & 0.154 & 0.165 & 0.16 & 0.149 & 0.152 \\
\hline $\begin{array}{l}\text { A06 } \\
\text { Innovative } \\
\text { Teaching }\end{array}$ & 0.164 & 0.163 & 0.171 & 0.17 & 0.164 & 0.086 & 0.166 & 0.166 & 0.173 & 0.176 & 0.164 & 0.167 \\
\hline $\begin{array}{l}\text { A07 Self } \\
\text { Study }\end{array}$ & 0.145 & 0.152 & 0.145 & 0.162 & 0.158 & 0.174 & 0.078 & 0.168 & 0.159 & 0.182 & 0.168 & 0.176 \\
\hline $\begin{array}{l}\text { A08 } \\
\text { Functional } \\
\text { Improvement }\end{array}$ & 0.15 & 0.154 & 0.168 & 0.169 & 0.154 & 0.173 & 0.162 & 0.077 & 0.159 & 0.164 & 0.163 & 0.164 \\
\hline $\begin{array}{l}\text { A09 } \\
\text { Learning } \\
\text { Environment }\end{array}$ & 0.154 & 0.165 & 0.165 & 0.171 & 0.152 & 0.167 & 0.159 & 0.155 & 0.081 & 0.167 & 0.166 & 0.164 \\
\hline $\begin{array}{l}\text { A10 } \\
\text { Learning } \\
\text { Motivation }\end{array}$ & 0.147 & 0.158 & 0.153 & 0.161 & 0.151 & 0.169 & 0.169 & 0.163 & 0.172 & 0.082 & 0.172 & 0.172 \\
\hline $\begin{array}{l}\text { A11 } \\
\text { Willingness } \\
\text { to Use }\end{array}$ & 0.152 & 0.162 & 0.154 & 0.164 & 0.151 & 0.171 & 0.17 & 0.161 & 0.165 & 0.173 & 0.079 & 0.165 \\
\hline $\begin{array}{l}\text { A12 Learning } \\
\text { Outcomes }\end{array}$ & 0.166 & 0.169 & 0.17 & 0.168 & 0.155 & 0.174 & 0.17 & 0.168 & 0.167 & 0.174 & 0.168 & 0.082 \\
\hline
\end{tabular}

Table 5. DEMATEL (D and R Values).

\begin{tabular}{|c|c|c|c|c|c|c|c|}
\hline & $\mathrm{D}$ & $\mathrm{R}$ & $\mathrm{D}+\mathrm{R}$ & $\mathrm{D}-\mathrm{R}$ & x Square of Difference & y Square of Difference & Sum of Squares \\
\hline A01 Mode of Use and Maintenance & 1.822 & 1.811 & 3.633 & 0.011 & 0 & 0.007 & 0.082 \\
\hline A02 Technology Investment & 1.884 & 1.859 & 3.743 & 0.025 & 0.001 & 0.001 & 0.038 \\
\hline A03 Market Competition & 1.721 & 1.88 & 3.601 & -0.159 & 0.025 & 0.013 & 0.196 \\
\hline A04 Classroom Operation & 1.828 & 1.884 & 3.712 & -0.057 & 0.003 & 0 & 0.057 \\
\hline A05 Education Trends & 1.841 & 1.769 & 3.611 & 0.072 & 0.005 & 0.011 & 0.126 \\
\hline A06 Innovative Teaching & 1.931 & 1.95 & 3.88 & -0.019 & 0 & 0.028 & 0.168 \\
\hline A07 Self Study & 1.867 & 1.821 & 3.687 & 0.046 & 0.002 & 0.001 & 0.053 \\
\hline A08 Functional Improvement & 1.859 & 1.815 & 3.674 & 0.044 & 0.002 & 0.002 & 0.059 \\
\hline A09 Learning Environment & 1.867 & 1.897 & 3.764 & -0.03 & 0.001 & 0.002 & 0.058 \\
\hline A10 Learning Motivation & 1.869 & 1.91 & 3.778 & -0.041 & 0.002 & 0.004 & 0.076 \\
\hline A11 Willingness to Use & 1.865 & 1.834 & 3.7 & 0.031 & 0.001 & 0 & 0.034 \\
\hline A12 Learning Outcomes & 1.931 & 1.853 & 3.784 & 0.078 & 0.006 & 0.005 & 0.105 \\
\hline
\end{tabular}


items have lower impacts than the other factors, meaning that it is necessary to derive solutions from individual problems or other factors. The average value of the total matrix, 0.15447 , is used as our standard value; wherever this standard value is surpassed, relationship lines can be drawn. We also establish a higher standard value of 0.17 , allowing us to make further distinctions between dashed lines (indicating standard relationships) and solid lines (stronger relationships). We have used this method to draw Figure 5, in which the arrows of the line segments are determined according to the degrees of causality $(D-R)$ in Table 5 : if the degree $(\mathrm{D}-\mathrm{R})$ is greater than 0 , the item is a causal item (i.e., a cause in the cause-and-effect relationship); if it is negative, the item is a resultant item (i.e., an effect in the cause-and-effect relationship). We use arrows to express the cause-and-effect relationship: if both items connected by a line are causal dimensions, the line segment has arrowheads at each end; if both items connected by a line segment are resultant items, the line segment appears as a simple line segment.

\section{Discussion and Conclusions}

The results of our study show that "technology investment" and "learning outcomes" are the most important decision-making factors related to the introduction of supplementary English education to future classrooms. Our observation of the education industry leads us to the same conclusion. In responding to future forms and modes of learning, technology investment is crucial to keeping pace with changing times. Because technological innovation generates innovation in teaching methods, the utilization of new technology for teaching produces significant improvements in learning outcomes and efficacy [17]. Improvements in and the wider application of information technology within learning environments promote technology investment in future classrooms, thus allowing various opportunities for interactive learning experiences as well as improvements in learners' cognitive abilities with regard to educational content, learning interest, and efficacy [18]. Core issues related to English learning include teacher capability, knowledge, and literacy in the use of technology; situational design and operation; and the application of in-class technology system resources [19]. Future classrooms make use of investments in technology and the revitalization of teaching outcomes, and can automatically create technological teaching environments around curriculum materials. After combining internet communication with system platforms, future classrooms will be better able to achieve the digital learning goals of "teach once and apply often" and "teach on site and share remotely," the new teaching framework sought by teachers, students, and management units [4]. The use of technology in language teaching can provide learners with varied interactive communication environments and pathways, reduce the stress of language learning, improve language learning motivation and self-confidence, and increase students' willingness to learn [20].

Much of the education literature indicates that an increasing number of 
learners support the efficacy of technology use in language education, as the use of technology broadens the boundaries of learning in both space and time [21]. The age of the learner is also a key factor in the effectiveness of language learning. Many parents worry that their children may lose out on early education. While early learning does provide benefits, it is not worth parental anxiety. Rather, learners should be provided with opportunities to develop their skills at a reasonable pace and a chance to become self-motivated, so that learning can be carried out without interruption and that effective English learning outcomes can be achieved [22]. This is especially true for childhood education in Taiwan. Taiwan's Supplementary Education Act encompasses short-term courses. Under time-constrained conditions, testing the efficacy of "teaching and learning" in the education service industry is even more important. Players in the education industry often use parent and student satisfaction as a measure of teaching efficacy; supplementary education places even greater importance on this index. Parental willingness to spend on additional education clearly implies a measurement index for their expectations and evaluations of education. Standard course selections are generally guided by education policy, while learning outcomes in supplementary education are reflected relatively directly. The most direct measurement of learning outcomes is the use of test performance results, in addition to performance with regard to class content, learning efficiency, and evaluation results. In a highly competitive market, learning outcomes are relatively direct. Addressing the value of knowledge transfer and the question of how to demonstrate its immediate effects and whether it can trigger related learning motivations are important tasks for the education industry. Due to the impacts of the rapidly developing linkages among technological development, the internet, and search engines, traditional education and modes of learning are facing unprecedented changes. The memorization required by students of the future will be assisted by search tools used to rapidly retrieve information, but it is still necessary to nurture the abilities to think, critique, distinguish, and analyze. Furthermore, teachers will not be able to adhere to traditional forms of classroom instruction, rely solely on machinery to engage in curriculum-based teaching, or teach according to standardized test score assessments. Investments in technology and the use of new technology will help teachers to merge "physical" with "virtual" education, reduce the learning gap, and improve overall learning outcomes. Future studies should continue to focus on topics related to trends in educational development and learning environments in order to increase the efficiency of education investments. Furthermore, Taiwan's experience in innovating supplementary education operation modes and feedback mechanisms to promote mainstream education should lead to improvements in the smart application of technology in future learning environments. The definition of "future classroom" varies based on individual interpretations. It is challenging to face existing education traditions, where clear variation is generated as a result of experts' evaluations of education or individual backgrounds and experiences. The form of the future classroom is in the development phase, and 
there is wide variation in the possible forms that it can take. The integration and acceptance of technology resources is an ongoing process, and levels of technology acceptance and use in teaching vary widely. The key factors in this variation are worthy of further research and in-depth discussion. Furthermore, developing education modes are causing expectations and speculation. The development of globalized education trends are influencing the promotion of educational directives, which vary greatly according to differing parental views on education. It is especially difficult to achieve consistent educational standards between cities and rural areas, which have differing education resources and environments. The optimal means of resolving these issues involves encouraging educational openness and providing a variety of learning channels and modes. Among these, supplementary education is an innovative industry deserving of further expansion. Greater resources should be invested in the development of supplementary education; the optimization of studies external to the system will then spur on the mainstream education system, in addition to making it possible to share education resources and experiences. Future classrooms are centered on learners and provide an interactive learning environment capable of addressing individual differences among them. The development of future classrooms will become necessary. Application modes for future classrooms will cross disciplinary boundaries, and resources should be suitably allocated to service design for modes of remote instruction, thereby bringing technology utilization to bear within the education industry. This may also create additional educational opportunities and allow for greater convenience in language learning.

\section{References}

[1] Bray, M., de Castro, B.V. and de Guzman, A.B. (2015) Confronting the Shadow Education System: What Government Policies for What Private Tutoring? The Asian Journal of Educational Research and Synergy, 3.

[2] Sung, P.F. (2010) The Use of Performance Evaluation Matrices to Explore the Educational Outcomes of Students. Master's Thesis, The Graduate School of Finance, Chaoyang University of Technology, Taiwan, 1-77.

[3] Chang, I.H., Hsu, C.M. and Chang, I.T. (2014) The Strategies of Integrating Information Technology into Classroom Management: A Discussion on the Innovative Application Model Smarter Classroom. Journal of Education Research, No. 239, $32-52$.

[4] Tu, J.C., Chiu, S.P., Chuang, L.W. and Chu, W.C. (2011) Research of Key Factors Influencing Online Learning Effectiveness of Distance Education. Journal of Cultural and Creative Industries Research, 3, 166.

[5] Zurita, G., Hasbun, B., Baloian, N. and Jerez, O. (2015) A Blended Learning Environment for Enhancing Meaningful Learning Using 21st Century Skills Emerging Issues in Smart Learning. Springer, Berlin, 1-8.

[6] Lopez-Perez, M.V., Perez-Lopez, M.C. and Rodriguez-Ariza, L. (2011) Blended Learning in Higher Education: Students' Perceptions and Their Relation to Outcomes. Computers \& Education, 56, 818-826.

[7] Stevenson, K. and Zweier, L. (2011) Creating a Learning Flow: A Hybrid Course Model for High-Failure-Rate Math Classes. EDUCAUSE Quarterly, 34. 
[8] Cross, N. (2011) Design Thinking: Understanding how Designers Think and Work. Berg Publishers Ltd., Oxford.

[9] Blomkvist, J. and Holmlid, S. (2010) Service Prototyping According to Service Design Practitioners. Paper presented at the 2 nd Nordic Conference on Service Design and Service Innovation.

[10] Kimbell, L. (2011) Designing for Service as One Way of Designing Services. International Journal of Design, 5, 41-52.

[11] Secomandi, F. and Snelders, D. (2011) The Object of Service Design. Design Issues, 27, 20-34. https://doi.org/10.1162/DESI_a_00088

[12] Segelström, F. (2009) Communicating through Visualizations: Service Designers on Visualizing User Research. Paper presented at the 1 st Nordic Conference on Service Design and Service Innovation, Oslo, Norway.

[13] Zomerdijk, L.G. and Voss, C.A. (2010) Service Design for Experience-Centric Services. Journal of Service Research, 13, 67-82. https://doi.org/10.1177/1094670509351960

[14] Sangiorgi, D. (2009) Building up a Framework for Service Design Research. Paper presented at the 8 th European Academy of Design Conference, Aberdeen, Scotland.

[15] Friedland, B. and Yamauchi, Y. (2011) Reflexive Design Thinking: Putting More Human in Human-Centered Practices. Interactions, 18, 66-71.

https://doi.org/10.1145/1925820.1925835

[16] Lee, W.S., Huang, A.Y., Chang, Y.Y. and Cheng, C.M. (2011) Analysis of Decision Making Factors for Equity Investment by DEMATEL and Analytic Network Process. Expert Systems with Applications, 38, 8375-8383.

[17] Hubbard, P. and Romeo, K. (2012) 3. Diversity in Learner Training. In: Stockwell, G., Ed., Computer-Assisted Language Learning. Diversity in Research and Practice, Cambridge University Press, Cambridge. https://doi.org/10.1017/cbo9781139060981.003

[18] Shetty, C.K.G. and Kolur, M. (2011) Interactive E-Learning System Using Pattern Recognition and Augmented Reality. Journal of Educational and Social Research, 1, 21-29.

[19] Chun, D., Smith, B. and Kern, R. (2016) Technology in Language Use, Language Teaching, and Language Learning. The Modern Language Journal, 100, 64-80. https://doi.org/10.1111/modl.12302

[20] Merchant, Z., Goetz, E.T., Cifuentes, L., Keeney-Kennicutt, W. and Davis, T.J. (2014) Effectiveness of Virtual Reality-Based Instruction on Students' Learning Outcomes in K-12 and Higher Education: A Meta-Analysis. Computers \& Education, 70, 29-40.

[21] Collins, L. and Muñoz, C. (2016) The Foreign Language Classroom: Current Perspectives and Future Considerations. The Modern Language Journal, 100, 133-147. https://doi.org/10.1111/modl.12305

[22] Muñoz, C. (2012) Intensive Exposure Experiences in Second Language Learning. Vol. 65, Multilingual Matters. 
Submit or recommend next manuscript to SCIRP and we will provide best service for you:

Accepting pre-submission inquiries through Email, Facebook, LinkedIn, Twitter, etc. A wide selection of journals (inclusive of 9 subjects, more than 200 journals)

Providing 24-hour high-quality service

User-friendly online submission system

Fair and swift peer-review system

Efficient typesetting and proofreading procedure

Display of the result of downloads and visits, as well as the number of cited articles Maximum dissemination of your research work

Submit your manuscript at: http://papersubmission.scirp.org/

Or contact ajibm@scirp.org 